\title{
Responsabilidade Moral e Identidade Empresarial
}

\author{
Hermano Roberto Thiry-Cherques
}

\section{Resumo}

Nesse artigo procuramos indicar os propósitos, as formas e os entraves na responsabilização social das empresas. Tendo em conta as implicações sobre a identidade empresarial e os meios de verificação do compromisso ético, sugerimos linhas de ação práticas para equalização dos problemas relativos à responsabilização moral das empresas.

Palavras-chaves: responsabilidade; ética; identidade; estratégia; empresas; moral.

\begin{abstract}
In this text, we made an effort to enumerate the purpose, the ways and the barriers to accomplish corporations' moral responsibility. In considering implications on organizational identity and also the level of ethics social commitment means of verification, we suggest some practical guidelines to equalize moral responsibility.
\end{abstract}

Key words: responsibility; ethics; identity; strategy; corporations; moral. 


\section{INTRODUÇÃO}

A responsabilidade social das empresas está em voga. Um número cada vez maior de empresas vem admitindo responsabilidades que transcendem as exigidas por leis e regulamentos. É verdade que a estabilidade e a integração social têm preocupado os empresários desde o advento dos distritos industriais (Piore, 1984). Mas há uma diferença substancial naquilo a que estamos assistindo hoje. É que a nossa capacidade de controle parece não mais dar conta dos riscos associados à atividade econômica.

De um lado, a produção industrial e a geração de serviços atingiram dimensão extraordinária. O temido feedback reverso já não é, infelizmente, uma especulação acadêmica. Os detritos do produzir estão entrando pelos sistemas de alimentação da economia que, naturalmente, começa a engasgar.

De outro, a educação e a facilidade de acesso às informações fizeram crescer a influência dos juízos sociais sobre investidores e consumidores. Por trás da informação e da produção integradas, todos podemos ver o complexo motor da atividade humana, com o seu lixo, vulnerabilidade e desregramento.

Foram esses dois fatores - a degradação e o conhecimento - que dispararam o alarme da responsabilidade. Ao que parece, os dirigentes e investidores finalmente entenderam que, em um mundo interligado, coeso e globalizado, não podemos despejar os problemas no quintal do vizinho. De uma forma ou de outra, ele devolve.

As empresas estão sendo chamadas à responsabilidade porque, havendo-se equivocado sistematicamente sobre o futuro da economia e da sociedade, vêemse na contingência de reavaliar o peso dos efeitos das suas atividades e corrigir a sua conduta. Elas estão sendo responsabilizadas pela indiferença, pelo equívoco e pela imprudência que nos trouxeram à situação de risco físico e espiritual em que nos encontramos, risco que, se efetivado, pode transtornar a vida econômica tal como a idealizamos.

Entre as atitudes possíveis para enfrentar esse desafio, a mais sábia parece ser a de sacudir a letargia e tentar dar conta do que está evidentemente errado. Trata-se de buscar nova identidade para as empresas, identidade que integre a responsabilidade social à área estratégica, logística, operacional, financeira e comercial. 
A identidade é mais do que a diferenciação da empresa em relação às demais organizações. É o que permanece, quando as estruturas, os processos e as pessoas mudam. É a face que a empresa apresenta a si mesma; por isso a responsabilização é mais complexa do que parece. As dificuldades são muitas. Para superá-las, é preciso antes de tudo compreender o que o conceito de responsabilidade encerra, bem como seus limites e implicações. No texto que se segue procuramos contribuir para essa compreensão, discutindo a responsabilização social das empresas na sua vertente ética e apontando um quadro referencial norteador da atuação nesse campo.

\section{Responsabilidade Social e Responsabilidade Moral}

A responsabilidade é a obrigação de respondermos por nossa conduta (Benthan, 1983) $)^{(1)}$. A responsabilidade social compreende o dever de pessoas, grupos e instituições em relação à sociedade como um todo, ou seja, em relação a todas as pessoas, grupos e instituições. A responsabilidade é o que nos faz sujeitos e objetos da ética, do direito, das ideologias e, se quisermos, da fé. É o que nos torna passíveis de sanção, de castigo, reprovação e culpa.

É importante a distinção entre a responsabilidade legal, institucional (políticoadministrativa) e religiosa, e a responsabilidade moral, que é o que aqui se discute. Elas têm a mesma raiz - spondere que quer dizer promessa. Re-spondere socialmente é cumprir com o compromisso mútuo entre o agente e a sociedade, é cumprir com a obrigação mútua (Cherques, 1997) ${ }^{(2)}$. Mas as obrigações das diversas responsabilidades são diferentes, seja pelo conteúdo que encerram, seja pelas instâncias de responsabilização.

\section{Figura 1: As Responsabilidades}

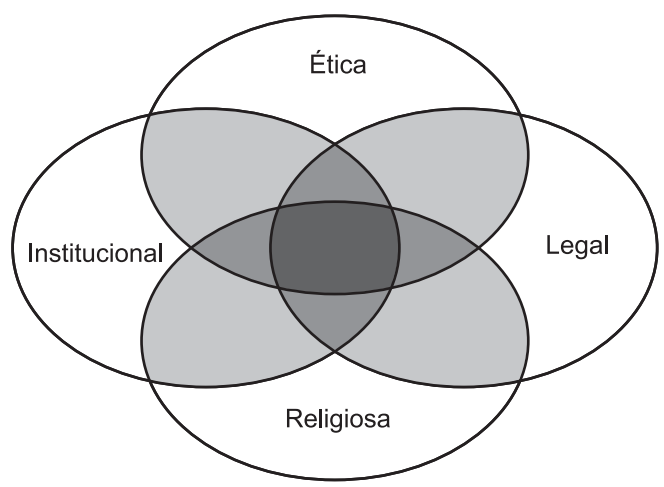


A responsabilidade legal diz que as empresas devem obedecer às leis, embora possam contestá-las e recusar as incongruências que, muitas vezes, encerram. A institucional, que têm a responsabilidade administrativa de obedecer a padrões reconhecidos nas relações que mantém com os outros atores sociais e os demais agentes econômicos, padrões que podem ser negociados, pactuados e repactuados. A responsabilidade religiosa é, ou deveria ser, uma questão adstrita a cada membro da organização. Já com a responsabilidade moral é diferente. A responsabilidade moral não é coercitiva, não é negociável e não é evidente. A responsabilidade moral é a única que não admite o equívoco e a evasão.

Também é preciso não confundir responsabilidades privadas e responsabilidades sociais A raiz spondere, de prometer, é a mesma dos esponsais, do casamento, que é uma responsabilidade privada. As responsabilidades moral, legal, institucional e religiosa do casamento são diferentes no que tange ao conteúdo e ao objeto da obrigação. Mas, sendo responsabilidades privadas, cujo objeto são indivíduos particulares, são claramente identificáveis, enquanto as responsabilidades sociais são dirigidas a categorias universais, a grupos, a instituições. Categorias difusas e muitas vezes sem voz. Mesmo porque ninguém ainda conseguiu operacionalizar satisfatoriamente, isto é, universalizar, conceitos como os de sociedade, vontade geral ou bem estar comum (Younkins, 2001).

Outra distinção que deve ser feita é a que separa a responsabilidade social moral da ética como um todo. A ética transcende em muito a responsabilidade. A ciência da ética opera sobre dois eixos. Um, teórico, busca determinar os fundamentos $^{(3)}$ da moral. Abarca o conhecimento que possa oferecer um princípio ou princípios norteadores do agir moral. O outro, que é um saber prático, se refere à aplicação desses fundamentos. Indica como devemos agir de forma a não ferir os princípios fundamentados pela ética. No conceito de responsabilidade social está contida, portanto, apenas uma das dimensões da ética, que é a do compromisso moral de responder sobre atos e intenções.

Como parte integrante da ética, a responsabilidade moral social tem por objeto as ações que possam, a qualquer título, vir a causar danos ou ofensas a outros. A esfera da responsabilidade social das empresas tem outras dimensões: a dimensão jurídica, a da imagem, a da coesão da organização, a dos elos institucionais, a da criação da riqueza e assim por diante. A esfera da ética, por seu lado, também transcende a questão da responsabilidade. Abarca questões tais como a solidariedade, os compromissos, a transparência, a fraude etc.

Em síntese, a responsabilidade moral social é segmento das obrigações éticas, circunscrito pela intersecção das esferas que o separam, em um plano, do direito, das instituições e da religião; em outro, da responsabilidade privada. Ser moralmente responsável é cuidar para que o output da empresa não repercuta negativamente 
sobre os seres humanos, incluindo as pessoas que ali trabalham. Isso compreende cada ser humano e a humanidade como um todo.

Aqui cabe um reparo. Cobra-se das empresas, a título de responsabilidade, ações como melhoramentos físicos, financiamento de projetos de interesse social e, até, caridade. Isso não tem nada que ver com responsabilidade. A responsabilidade moral das empresas esgota-se na prevenção dos males que possam causar e na reparação daqueles que vieram a causar, sem ter a intenção de fazê-lo.

\section{Responsabilidade e Accountability}

A responsabilidade é distinta da sujeição à prestação de contas (accountability). Embora ambas compartilhem a implicação de pena, a sujeição à prestação de contas é essencialmente externa à pessoa ou à empresa, isto é, depende da instância à qual se deve prestar contas, enquanto a responsabilidade está referida essencialmente ao objeto do dever, à obrigação moral ${ }^{(4)}$.

Na prática, a pauta das responsabilidades tem duas fontes primárias: a própria accountability e o exercício reflexivo e discricionário da razão (Pennock, 1960). A segunda destas fontes, a da razão, também admite duas acepções: (1) responsabilidade como consideração da conseqüência de uma ação; e (2) a responsabilidade como o reconhecimento de uma obrigação. É essa última acepção do termo que corresponde à responsabilidade moral.

A responsabilidade social moral pode ser descrita por exclusão. Como vimos, ela é distinta das responsabilidades legal, institucional e religiosa, ainda que, como parte da ética, a elas se integre. Distingue-se também da responsabilidade privada, da sujeição à prestação de contas e da preocupação com as conseqüências dos atos. Por último, a responsabilidade moral tem dois antônimos. A irresponsabilidade - que é a ação ou a intenção de agir conscientemente contra a razão - e a "não-responsabilidade”, que é a não percepção - a não-consciência de que a ação ou a intenção de agir podem causar danos ou ofensas a terceiros.

\section{Responsabilidade Moral das Empresas}

O que geralmente se denomina a responsabilidade social das empresas limitase ao direito, à obrigação de responder perante a lei. Isso porque as empresas não são agentes morais. Só os seres humanos o são. O domínio de significação 
ética circunscreve-se ao comércio entre os seres humanos. Apenas as pessoas nas empresas, os dirigentes e empregados têm responsabilidade moral. As instituições, as organizações, o Estado, os sistemas econômicos e políticos são resultantes das lutas por poder, do confronto de interesses econômicos, do processo evolutivo e do azar. Não têm consciência, não são e não podem ser atores morais, sujeitos da eticidade. Quem tem responsabilidade moral são as pessoas. A responsabilidade moral das pessoas nas empresas é a mesma de todos nós: preservar para os seres humanos a integridade da sua essência e do seu mundo contra os abusos do seu próprio poder e do poder alheio.

Por essa razão, ao contrário do muito que se tem escrito e dito, não há base lógica que dê sustentação à idéia de uma "ética corporativa". Em pelo menos uma coisa Milton Friedman concorda com a esquerda esclarecida. As empresas são entes amorais. O que define a empresa é a busca do seu próprio interesse econômico. Considerar que elas fazem outra coisa é uma hipocrisia. Diz ele, em texto que ficou famoso: "só as pessoas podem ter responsabilidades. Uma corporação é uma pessoa artificial [jurídica] e, nesse sentido, pode ter responsabilidades artificiais [legais], mas "os negócios", como uma totalidade, não se pode dizer que tenham responsabilidades, nem sequer em sentido vago” (Friedman, 1970).

Por definição, a firma, seja ela considerada como elo do processo produtivo, conjunto de contratos ou sistema organizacional, não é ente moral. Quem tem responsabilidade são as pessoas nas empresas. Tanto as que as dirigem como as que contribuem para o que a empresa faz. A responsabilidade moral é a que temos, nós seres humanos, perante os grupos, as comunidades e a sociedade e não vice-versa ${ }^{(5)}$.

Só ao "tomarmos consciência”, podemos agir moralmente. No plano individual esse é um problema que muitas vezes assume dimensões trágicas. Afinal, Édipo poderia ter sido responsabilizado? Ele sabia o que fazia? A sua culpa, se culpa teve, foi a de não interpretar corretamente o enigma da sua própria vida. Mas ele se culpou e se cegou, o que foi, claro, inútil porque a consciência não é exterior, não é algo que possamos abandonar ou deixar de ver. No plano empresarial, a dificuldade se multiplica pela quantidade de instâncias com as quais as pessoas têm deveres e pela contradição entre os interesses de umas e de outras. Afinal, um dirigente é mais responsável perante os empregados ou perante os acionistas? Um empregado deve ser fiel aos colegas ou a sua família? Não há instância exterior à consciência que possa dar conta dessas questões.

O fato de a tradição religiosa e o pensamento filosófico não admitirem a sanção coletiva, não significa que as empresas não possam ser responsabilizadas socialmente. Podem, e são. Pelo direito, como pessoas jurídicas, pelos mercados, como marca rejeitada, ideologicamente por condenações como a do boicote e, também, 
pela moral, só que aí não mais como entes coletivos, senão que na pessoa dos seus acionistas, dirigentes e empregados.

As responsabilidades sociais especificamente morais das pessoas nas empresas abarcam ampla gama de categorias. Todos nós respondemos perante instâncias diversas pelos nossos atos. No caso do direito, respondemos ante os tribunais; no caso da religião, respondemos perante a divindade; no caso das idéias, respondemos ante nossos amigos e confrades; no caso da ética, respondemos à nossa consciência. Desse último ponto de vista, a responsabilidade social das empresas compreende o conjunto de deveres morais que as empresas, na pessoa dos que as dirigem, têm para com a sociedade. Esses deveres são de caráter preventivo, por exemplo, quando a empresa se esforça por não deteriorar o meio ambiente, e de caráter reparador, quando, por exemplo, a empresa restaura o meio ambiente depois de um vazamento de efluentes.

Além do tão comentado meio-ambiente, as pessoas nas empresas são moralmente responsáveis por uma gama variada de agravos potenciais, que inclui todos os atos que possam causar dano aos seres humanos. A responsabilidade é sobre o mundo físico; mas também sobre o mundo espiritual, sobre tudo aquilo que possa afetar a integridade da essência do ser humano. Os acionistas, dirigentes e empregados têm a obrigação moral de não permitir que a empresa venha a poluir, a infectar, a desvalorizar, a perturbar etc. Têm a obrigação moral de obedecer a padrões éticos, espirituais, institucionais, sociopsicológicos, e assim por diante.

\section{Restrição Ética e Regulação Legal}

A responsabilidade jurídica, civil ou penal diferencia-se da responsabilidade ética por ser, necessariamente, posterior ao dano. Ninguém pode ser punido legalmente pelas intenções que tenha. $\mathrm{O}$ que as leis obrigam é que as pessoas e as empresas reparem o dano que fizeram a outrem. O direito atua preventivamente, pela dissuasão. Isso tem que ver, historicamente, com a vingança, ou melhor, com o medo da vingança, seja ela pessoal, seja societária.

A responsabilidade moral, pelo contrário, tem que ver com o respeito, com a prevenção solidária. Um dos exemplos mais óbvios dessa distinção é dado pelo tabagismo. As pessoas e empresas que fabricam, vendem e, de qualquer forma, ajudam e permitem a fabricação, a venda e o consumo de cigarros, agem legalmente. Estão dentro da lei. Eticamente, no entanto, sabendo o que sabemos hoje - e que, aliás, foi admitido pelas empresas do setor fumageiro norte-americano sobre as enfermidades e as mortes decorrentes do tabagismo, essas pessoas são 
responsáveis por contribuir para uma epidemia sanitária. Para elas, não há, moralmente, desculpas, atenuantes ou indenizações que dêem jeito. À diferença da responsabilidade legal, a responsabilidade ética não compreende a reciprocidade, a retribuição, o ressarcimento.

No plano das empresas, o refúgio na ignorância menos ainda se justifica. Não há como escapar à lógica de que, do ponto de vista ético, havendo dano ou ofensa que seja inerente à atividade empresarial, então essa atividade deve ser suspensa. Se a atividade for essencial, há que se cuidar para que as pessoas prejudicadas possam ser protegidas e, se for o caso, ressarcidas. "Atividade essencial” no contexto ético quer dizer atividade imprescindível para a humanidade, como a atividade hospitalar, que é necessária, embora possa ser prejudicial às pessoas que vivem perto dos hospitais. É diferente do conceito de atividade economicamente essencial.

Ao contrário do que muitas vezes se argumenta, a restrição moral, se efetivada, não impediria um número significativo de atividades empresariais. Isso porque há diferença substancial entre o efeito não desejado e o efeito não previsto. Quando a empresa, conscientemente, pratica um ato danoso ou ofensivo ao ser humano, ela pratica uma iniqüidade. Quando alguma coisa não prevista acontece, ela pratica uma imprudência. Juridicamente trata-se do dolo e da culpa. Nenhum dos dois é descupável. Apenas a pena é menor no segundo caso. Moralmente, a iniqüidade é indesculpável, enquanto a imprudência pode ser relevada. O problema é quando as conseqüências não previstas são previsíveis. É o que se chama em filosofia moral de ato de duplo efeito. Um exemplo de duplo efeito é dos remédios que são dados a pessoas com doenças terminais. Uma coisa é abreviar a vida para livrá-las da dor. Isso é condenado por muitas pessoas e instituições, como a Igreja Católica, embora venha sendo praticado em vários países. É, no mínimo, uma prática discutível. Outra coisa é utilizar remédios que diminuam a dor, mesmo que seja previsível que esses remédios possam abreviar a vida. E aí a intenção e o ato já são completamente diferentes.

Da mesma forma, existem atividades empresariais que têm duplo efeito. Por exemplo: gerar empregos e aumentar a poluição. $\mathrm{O}$ ato de responsabilidade social consiste em atenuar ao máximo os efeitos dessa poluição, sem deixar de gerar o emprego. No entanto, moralmente, se houver poluição, ou mesmo o risco de poluição, que não puder ser controlado, o efeito positivo da geração de empregos não se justifica. A imprudência torna-se iniqüidade. Esse é o caso do asbesto, uma substância que é mortal e que está no amianto e em uma série de produtos como roupas, embalagens etc. Evidentemente, não há racionalização econômica que justifique eticamente permitir a manipulação dessa substância.

Estabelecida a distinção entre responsabilidade social de caráter moral e res- 
ponsabilidade social legal, devemos insistir em que a responsabilização ética das empresas não pode, de forma alguma, ser vista como substituta da regulação e da legislação, principalmente a referente a direitos individuais e sociais e à proteção da vida, incluindo-se aí a legislação ambiental. O direito é, e sempre será, insubstituível na aplicação positiva da ética consentida e no resguardo da moralidade concertada. O esforço de responsabilização moral deve estar voltado principalmente para as áreas onde a legislação não existe ou é precária, seja por atrasos e deficiências do processo legislativo, seja pela dificuldade em legislar sobre matéria controversa ou sobre tópicos recentes, como aqueles relativos à Internet, por exemplo.

\section{O Limite da Responsabilidade}

Do ponto de vista ético, não há limite de responsabilidade para os danos sociais que uma empresa possa causar. A idéia de limite de responsabilidade vem do direito civil e do comercial. Os proprietários de empresas de responsabilidade limitada só respondem pelo seu patrimônio social. Mas esta é uma figura econômica e jurídica. Moralmente não há limite para a nossa responsabilidade. O que existe é a não-responsabilização sob determinadas condições.

Não respondem moralmente pelos seus atos as pessoas com capacidades volitivas e cognitivas imperfeitas ou incompletas, isto é, os dementes e as crianças pequenas. Na filosofia moral, a responsabilidade está intimamente ligada à liberdade. A imputação da responsabilidade supõe que a pessoa, grupo ou instituição seja um ser livre de determinações exteriores e interiores. Isso gera muita controvérsia sobre a imputabilidade das pessoas que agem por coação de força maior, por ignorância, por equívoco e por constrangimentos de ordem cultural, educacional e circunstancial. Alguns filósofos, como Aristóteles, consideram atenuantes para esses casos. Outros, como Kant, não(6).

O fato é que se pode fugir à lei, mas não à consciência. Não podemos ignorar as responsabilidades morais que temos, sob pena da perda da nossa própria dignidade. Sócrates, que sabia tudo embora o negasse, ensinava que ninguém é mau porque quer, ninguém adquire um vício porque quer ${ }^{(7)}$. Ele e Platão acreditavam que há duas espécies de demência: a loucura e a ignorân$\mathrm{Cia}^{(8)}$. Talvez seja sensato concordar com eles e dizer que muita gente simplesmente ignora as responsabilidades que tem. Mas não podemos esquecer que outra linhagem de pensamento, inaugurada por Aristóteles, diz que não, que a maldade é voluntária, que a ignorância e a negligência não são a mesma $\operatorname{coisa}^{(9)}$. Para essa ordem de pensamento, se ignoramos as responsabili- 
dades que temos, é porque fugimos de nos educar, já que é pelo exercício que se formam as disposições de caráter.

Seja como for, o compromisso ético é construção da razão, construção que considera o egoísmo como parte da natureza humana. A ética demonstra, por diversas vias, que a conduta moralmente legitima é do nosso interesse, do interesse das pessoas dotadas de razão, que é do nosso interesse egoísta superar o egoísmo. Quando a ética trata de chamar à razão as pessoas que dirigem ou apóiam as empresas que produzem bens e serviços nocivos, ela o faz mediante argumentos racionais, vale dizer, não emocionais. Isso porque a responsabilidade social é, logicamente, antecedida e conformada pela responsabilidade privada, a responsabilidade que temos conosco mesmos. A responsabilidade social é o respeito que temos ou que deveríamos ter pelos outros. A responsabilidade privada é o respeito que temos ou deveríamos ter por nós mesmos; é a dignidade. Como esperar que alguém que não cuida de si mesmo tenha responsabilidade social, se nem responsabilidade privada ele tem?

\section{Responsabilidade e Gestão}

Na atividade empresarial moderna a responsabilização direta não é simples. A principal dificuldade no nível das operações decorre do alongamento das linhas de produção e da complexidade do processo de geração de bens e serviços. Cada vez mais nossas ações no trabalho produtivo se distanciam dos seus efeitos. Como não existe responsabilidade sem conhecimento - seria o caso da não-responsabilidade - a alienação, a ignorância da real ou suposta impossibilidade de conhecermos os efeitos daquilo que ajudamos a criar, tem sido o álibi de investidores, acionistas, dirigentes e empregados. Como álibi, inocenta, mas não desculpa.

Outra dificuldade reside no gerenciamento de dupla face. O declínio das doutrinas de responsabilização econômica, que obrigam os gerentes a aderirem cegamente aos propósitos corporativos, tem levado não a maior democratização ou humanização da gerência, mas a uma linha de escape institucional. Os gerentes chamados a servir a dois senhores - os investidores e a comunidade - tendem a servir a si mesmos, utilizando os interesses de um como desculpa para o descaso com os do outro (Marcoux, 2000).

No nível da gestão de negócios, as questões que se levantam são ainda mais complexas. Em livro recente, elas foram corajosamente alinhadas por um antigo economista-chefe da Comunidade Européia, o professor David Henderson. Diz ele que os 
executivos estão sendo chamados a ser “'bons cidadãos', a atender à necessidade dos "stakeholders", a contribuir para o desenvolvimento sustentável e a elevar o 'padrão ético'” (Henderson, 2001). Henderson (2001) chama isso de "salvacionismo global” e o vê como ameaça intelectualista ao funcionamento do capitalismo. Segundo ele, a resposta das corporações às ameaças da sociedade são uma capitulação ante uma visão absurda de como a economia funciona e que tem gerado mais mal do que bem; por exemplo, aumentando custos e preços, favorecendo regulações burocratizadas, eliminando possibilidades de diferenciação, via padronização burra de processos, reduzindo as possibilidades de competição, até mesmo e principalmente nos países menos desenvolvidos, em face do mercado global. Em suma, a voga da responsabilização tem trazido mais infortúnios sociais do que o bem que apregoa. Esta é opinião fundamentada, e um alerta contra exageros. No entanto, o que as informações disponíveis hoje indicam, é que a resposta está em equilíbrio, no propósito, mais do que na esperança, de que a liberdade do mercado possa conviver com a minimização dos problemas trazidos pelo capitalismo.

\section{Responsabilidade E INTERESSE}

Claro está que não é a consciência, que não possuem, nem o medo a punições legais, de que se podem defender, que têm levado as empresas a se preocuparem com a responsabilidade social. Os principais fatores que as animam são a busca de uma imagem comercialmente conveniente, a procura de vantagens competitivas em ambiente de concorrência incivil, e os reclamos decorrentes dos danos sociais provocados por suas atividades. Há também, entre os empresários mais esclarecidos, um componente ideológico. Pouca gente se lembra, mas o propósito do liberalismo econômico é o de gerar bem-estar social. Adam Smith pretendia que os particulares, "guiados pela mão invisível do mercado promovessem simultaneamente o interesse da sociedade"(10).

A resposta à exigência por maior responsabilização social das empresas tem levado a duas conseqüências. Uma, previsível, é a construção da imagem da responsabilidade, uma espécie de blindagem contra as suspeitas do público e a maledicência da competição. Outra, louvável, mas ainda incipiente, é a restrição efetiva à possibilidade de danos e ofensas, e a reparação dos danos sociais decorrentes da atividade empresarial.

A proteção da imagem é, o mais das vezes, interesseira. Tem pouco ou nenhum valor moral. Ela se dá em três níveis: o de esconder os pecados, o de desenvolver projetos com fins publicitários e o de ostentar os feitos - o chamado "marketing com causa” ${ }^{(11)}$. O primeiro nível, o da maquilagem dos danos sociais é eticamen- 
te intolerável. O segundo é também problemático. Na procura pelos holofotes publicitários, o foco de luz se derrama muitas vezes sobre projetos de socialites, que nada têm que ver com as mazelas causadas pela atividade empresarial, ou sobre projetos que são simples obrigações legais, que teriam de ser feitos de qualquer jeito e que não são nem liberalidade nem bondade. O terceiro nível, o do marketing com causa, é decorrente do tipo de economia em que vivemos e não é, em si, incorreto. A inversão em imagem é legitima, desde que não se trate de buscar o próprio interesse à custa dos outros. Se praticar o bem coincide com o interesse econômico, ótimo. Afinal, porque não deveria ser feito? Claro está que não há mérito moral nisso. Mas também não há demérito algum.

Felizmente, há hoje um esforço não desprezível no sentido de dar organicidade à efetiva responsabilização social das empresas. Desde o início dos anos noventa, as empresas da Europa concordam que é sua responsabilidade a educação continuada, a igualdade de oportunidades, a inclusão social e o desenvolvimento sustentado (CRS, 1996). Em todo o mundo, movimentos, campanhas e organizações estão se instituindo com esse propósito ${ }^{(12)}$. Existem mesmo declarações internacionais de orientação estratégica das empresas na inclusão de diretrizes e parâmetros de responsabilização social em seus planos de negócios ${ }^{(13)}$. O entendimento dessas iniciativas é bastante claro: trata-se de responsabilidades que as empresas assumem para além do simples cumprimento das obrigações legais.

\section{Áreas de Responsabilização Moral}

As áreas em que a responsabilização moral tem sido mais freqüente são as relacionadas com a vulnerabilidade da natureza. Desde os gregos, excetuando o que se refere à saúde e à vida, o comércio entre os seres humanos e o mundo exterior é considerado neutro do ponto de vista da ética. Mas nós, a humanidade, dependemos da natureza para continuar existindo. Não se trata só, nem principalmente, do que podemos fazer à natureza, mas do que, interesseiramente, nos pode faltar na natureza. Daí a importância da medicina e do meio ambiente nas discussões sobre a responsabilidade social. Hoje entendemos melhor que a preservação, seja a do corpo seja a da biosfera, é uma relação de duplo sentido, uma relação de dupla dependência. E a cada dia surgem problemas inteiramente novos nesse campo. A questão do controle genético transcende em muito saber se faz bem ou mal à saúde a ingestão de produtos modificados. Aí está a clonagem para nos fornecer hominídeos dotados de razão via reprodução assexuada ${ }^{(14)}$.

Mas a responsabilidade social das empresas não se limita à bioética e à questão ambiental. As organizações resistem, como é de se esperar, à inclusão de novos 
itens. Ninguém, livremente, anseia por assumir encargos, muito menos as companhias, preocupadas que estão em sobreviver em ambiente econômico e administrativo cada vez mais complexo e errático. No entanto, na medida em que as empresas consideradas socialmente responsáveis têm obtido retorno maior do que as demais firmas do mesmo setor, as resistências vão, pouco a pouco, cedendo espaço para a adesão e até mesmo para algum entusiasmo ${ }^{(15)}$.

Uma classificação de todos os itens de responsabilidade social das empresas ainda está por ser universalmente aceita. A que temos utilizado foi elaborada com base na literatura técnica da filosofia moral e, posteriormente, corrigida e resumida a partir dos itens adotados por organizações brasileiras, norte-americanas e de diversos países da Europa. O Quadro 1, abaixo, sintetiza os valores considerados na responsabilização moral.

\section{Quadro 1: Campos da Responsabilização Moral Social}

\begin{tabular}{|c|c|c|}
\hline \multirow{12}{*}{ Valores vitais } & \multirow{12}{*}{$\begin{array}{l}\text { agravos potenciais ou atuais aos } \\
\text { alimentos, à água, ao abrigo e ao } \\
\text { socorro }\end{array}$} & agressões a ecossistemas \\
\hline & & degradação de recursos naturais \\
\hline & & degradação do solo \\
\hline & & degradação sonora \\
\hline & & destruição da biodiversidade \\
\hline & & poluição luminosa \\
\hline & & produtos nocivos \\
\hline & & qualidade da água \\
\hline & & qualidade do ar \\
\hline & & resíduos sólidos \\
\hline & & saúde preventiva \\
\hline & & segurança industrial \\
\hline \multirow{11}{*}{$\begin{array}{c}\text { Valores } \\
\text { humanísticos }\end{array}$} & \multirow{11}{*}{$\begin{array}{c}\text { agravos potenciais ou atuais à } \\
\text { dignidade, à liberdade e aos valores } \\
\text { culturais }\end{array}$} & deslocamento populacional forçado \\
\hline & & educação \\
\hline & & exclusão social \\
\hline & & liberdade de expressão \\
\hline & & restrição de ir e vir \\
\hline & & privacidade individual \\
\hline & & trabalho forçado \\
\hline & & trabalho infantil \\
\hline & & transparência e acesso \\
\hline & & valores estéticos \\
\hline & & valores religiosos \\
\hline \multirow{9}{*}{ Valores utilitários } & \multirow{9}{*}{$\begin{array}{c}\text { agravos potenciais ou atuais à } \\
\text { capacidade de geração de riquezas e } \\
\text { de sua distribuição }\end{array}$} & administração de sobras e recicláveis \\
\hline & & depreciação de ativos de terceiros \\
\hline & & desvalorizações \\
\hline & & igualdade de oportunidades \\
\hline & & prevenção e emergência \\
\hline & & segurança no trabalho \\
\hline & & sonegação de informação \\
\hline & & propaganda enganosa \\
\hline & & supressão tecnológica \\
\hline
\end{tabular}


O segundo eixo da responsabilização moral é o da identificação do referente, vale dizer, a determinação de saber perante quem a empresa se responsabiliza.

Conforme a tradição de cada cultura, a responsabilidade está referida preferencialmente ao passado, ou ao presente, ou à vida futura. Na tradição do pensamento do ocidente, as máximas da responsabilidade estão referidas, de modo geral, à vida presente. Devemos amar ao próximo como a nós mesmos, subordinar o bem-estar pessoal ao bem-estar comum, tratar o próximo não como meio, mas como fim em si mesmo (Jonas, 1990). Na tradição do pensamento oriental, somos responsáveis, principalmente, perante os que nos antecederam, os nossos antepassados. Já a filosofia moral contemporânea insiste em que somos responsáveis sobretudo perante a humanidade presente e futura. Ser responsável hoje é, em grande medida, ter sido feito refém dos que estão por vir, preocuparnos com os que ainda não nasceram, olharmos mais adiante, para o mundo que estamos construindo cada dia e do qual não participaremos.

Na instância legal e política, os referentes da responsabilidade são institucionais. Na instância religiosa, o referente é transcendental. Na instância ética, os referentes são mais difíceis de serem precisados. Existem responsabilidades naturais, como aquelas que temos para com nossos filhos, para com a nossa comunidade e para com a humanidade como um todo; e responsabilidades contratuais, que são as que escolhemos livremente. O dano à propriedade, por exemplo, não é, em si, uma responsabilidade natural. Alguns pensadores, como Bentham (1985), consideraram até o compromisso moral com os seres viventes. Ele é o autor das primeiras leis de proteção dos animais. O que hoje é geralmente admitido é a idéia da moralidade como atributo da razão, como queria Kant, isto é, como atributo dos seres humanos. Isso fixa a responsabilização essencialmente como o dever perante pessoas e grupos humanos, que existem, que existiram no passado e que possam vir a existir.

Uma classificação que se aproximasse do muito que foi dito e escrito sobre a responsabilidade moral social conteria os itens do Quadro 2, a seguir. 


\section{Quadro 2: Instâncias na Responsabilidade Moral das Empresas}

\begin{tabular}{|c|c|c|}
\hline \multirow{5}{*}{ Naturais } & & comunidade \\
\hline & & famílias \\
\hline & & futuras gerações \\
\hline & & humanidade \\
\hline & & sociedade \\
\hline \multirow{11}{*}{ Contratuais } & Trabalho/empresa & empregados $(*)$ \\
\hline & & terceirizados \\
\hline & Trabalho/trabalho & representações trabalhistas \\
\hline & \multirow{2}{*}{ Empresa/reguladores } & autoridades \\
\hline & & reguladores não governamentais \\
\hline & \multirow{6}{*}{ Empresa/empresa } & acionistas \\
\hline & & clientes \\
\hline & & parceiros \\
\hline & & investidores \\
\hline & & fornecedores \\
\hline & & concorrentes \\
\hline
\end{tabular}

(*) Essas instâncias têm, cada uma, referências a campos específicos. Por exemplo, nas relações entre a empresa e seus empregados, consideramos como atinente à responsabilidade moral principalmente os campos da transparência nas informações, condições de lazer, igualdade de pagamento, oportunidades para portadores de deficiências, oportunidades para idosos, privacidade, saúde e segurança do trabalho.

\section{A Socialização da Responsabilidade}

A todo o momento estão aparecendo novas responsabilidades e novas instâncias de responsabilização. É que o domínio técnico que adquirimos significou um avanço incomensurável na possibilidade de realização plena dos valores vitais - a preservação e o alongamento da vida - e dos valores utilitários - o conforto que desfrutamos era inimaginável há cem ou cinqüenta anos. O impacto da tecnologia sobre a vida espiritual tem, também, um lado negativo. A técnica sempre serviu à cultura, o homo sapiens é uma evolução do homo faber; hoje, o homo faber, a parte servil do homo sapiens, está ameaçando impor-se sobre ele ${ }^{(16)}$ (Jonas, 1990). O sistema está colonizando o mundo da vida (Habermas, 1987) e as empresas são os mediadores desse processo.

Obviamente, esse é um movimento que não pode ser detido; mas, se todos compreendermos que isso acontece e como isso acontece, as chances de reverter o seu sentido nocivo são muito boas. Se de um lado a cobrança por maior responsabilidade das empresas aumentou na medida em que aumentaram a compreensão dos efeitos a longo prazo das nossas ações, por outro nos tornamos muito poderosos. Pela primeira vez na história, o nosso poder de fazer, seja o poder de fazer uma vacina, seja o poder de fazer a guerra, está acima do nosso 
poder de julgar e do nosso poder de prever as conseqüências. Há muito o homo faber que temos em nós deixou de ser o que simplesmente fabrica os meios de sua subsistência. Hoje fabricamos e destruímos o mundo de acordo com as nossas necessidades. A responsabilidade é enorme, temos cometido erros brutais, mas as possibilidades e os instrumentos de correção não nos faltam.

As empresas têm como responder ao desafio da desintegração social. A dificuldade maior a ser superada é que a esperança de prevenir o desastre público parece tão remota para a maior parte das pessoas, que entra em seu pensamento apenas na forma de uma melancólica súplica em favor da paz e da fraternidade (Lasch, 1990). Súplicas, lamentos, discursos políticos e coisas do gênero não levam a nada. É claro que algumas situações são nitidamente difíceis. Como no caso do uso de drogas pelos que formam a comunidade empresarial. A responsabilidade fica presa entre a omissão e a ingerência indevida; mas a atuação internacional e os protestos ou revides, como ficou claro em Seattle, 2000, não são movimentos isolados: são um alerta e uma indicação de que não podem ser ignorados.

Há muito que ser feito. As pessoas envolvidas com o destino das empresas devem informar-se e devem discutir mais a questão da responsabilidade e a da ética em geral. Estrategicamente, o que está em jogo é a identidade da empresa. O conjunto de elementos pelos quais a empresa se constitui a si mesma, pelos quais a empresa adquire personalidade própria ${ }^{(17)}$. Moralmente o imperativo reside em que não podemos deixar de nos informar e de agir ${ }^{(18)}$. Precisamos determinar, por exemplo, quais práticas empresariais são aceitáveis e codificá-las. Deve haver um estatuto consentido; porém de nada adiantam as normas privadas e as leis, se não há conscientização. Como a negligência moral não tem outra sanção do que a dor nas consciências, é preciso que haja mais conscientização, que nos envolvamos mais.

Uma sociedade informada e articulada em torno de valores básicos dispensa leis draconianas. As leis são úteis mais como remédios, uma vez que se aplicam sobre $\mathrm{o}$ ato praticado. A lei não pode punir a intenção de fazer o mal. Para que se aplique a lei, é preciso que a pessoa ou a empresa tenha praticado ato ilícito ou se tenha omitido, intencionalmente ou não. $O$ direito impõe deveres negativos, interdições: não fazer isso, não fazer aquilo. Já os sistemas éticos propõem deveres positivos, em geral deveres de solidariedade, de fidelidade, de lealdade etc. Por exemplo, a lei proíbe a mendicidade, enquanto o que a moral recomenda é que amparemos o desvalido.

A função da sanção ética é dissuadir, não punir. Como vimos, não funciona sobre quem não tem consciência formada - as crianças e os dementes - e sobre quem não tem a liberdade de decidir, sobre os que agem sob coação. É a nossa 
consciência que nos move e nos freia. Essa é a função da ética. Mesmo porque depois do mal feito, não há conserto; só remendo. Aristóteles ${ }^{(19)}$ diz que quem arremessa uma pedra já não pode alcançá-la. Os espanhóis dizem, talvez muito melhor, que a palo dado, ni Dios lo quita (a bordoada dada, nem Deus tira).

\section{Conclusão}

A conscientização sobre a responsabilidade moral social começa pela socialização das responsabilidades, o avanço da noção de corresponsabilidade. Nós, brasileiros, temos alguns traços culturais muito simpáticos. Outros nem tanto. Tendemos a socializar o bem e a individualizar o mal. Quando ganhamos a Copa do Mundo, dizemos que o Brasil ganhou. Quando fracassamos, dizemos que a seleção perdeu. É preciso que entendamos que nós, os cidadãos de bem, que cumprimos a lei, somos, todos, em menor ou maior escala, igualmente responsáveis pelo bem e pelo mal que aí estão. Temos de responder por isso. Cada um responde como lhe cabe. Os excluídos dão a resposta que dão a sociedade que os destituiu não só da dignidade, mas da possibilidade da dignidade, da esperança. Nós, as pessoas nas empresas, investidores, acionistas, dirigentes e empregados, que recebemos da sociedade mais do que demos a ela, temos a obrigação moral de retribuir de alguma forma. Mesmo porque isso é do nosso interesse. Claro está que ninguém, a não ser nós mesmos, tem o direito de nos dizer como devemos exercer individualmente a nossa responsabilidade moral. Em compensação, a negligência ética não tem tribunal exterior à consciência, ao qual possamos apresentar atenuantes e suplicar perdão.

O caminho a percorrer para a responsabilização moral ainda é longo. A compreensão dos itens aqui examinados é apenas começo. Distinguir, no imenso campo da responsabilidade social, aquilo que é atinente à ética, separando-a, por exemplo, do que é atinente à convicção política, ajudaria a hierarquizar as orientações estratégicas. O mesmo vale para a distinção entre responsabilização moral, regulação legal e accountability. Para benefício mútuo, as três esferas devemse complementar sem se confundir. Circunscrever a responsabilidade ao que, tecnicamente, lhe corresponde - os danos e as ofensas potenciais ou efetivos permitiria focar as ações no que é essencial, eliminando desperdícios de tempo e de gastos. A integração da responsabilidade ética ao planejamento e à governança das organizações, para além de ser exigência societária cada vez mais presente, traria os benefícios decorrentes da transparência administrativa e do gerenciamento de encargo compartilhado, alavancando o aprendizado e o aperfeiçoamento de métodos e processos. 


\section{Notas}

${ }^{1}$ Com essa definição, o termo aparece pela primeira vez no texto de Jeremy Benthan, A Fragment on Government, de 1787.

${ }^{2}$ A responsabilidade como dever perante as instituições é o que faz Max Weber separá-la da "ética das convicções”. A discussão sobre a impossibilidade de conciliar duas éticas, uma da responsabilidade e outra da convicção, foi tratada pelo autor em um texto específico.

${ }^{3}$ Fundamentado quer dizer legitimado teoricamente a partir de juízos inteligíveis.

${ }^{4}$ A respeito da accountability ver Campos (1990). Uma fonte importante de informações pode ser encontrada no Social Accountability 8000 (SA 8000).

${ }^{5}$ A tradição greco-judaico-cristã de responsabilização é sempre pessoal. Aristóteles (vide Livro III, cap.5, 1113b) diz que somos responsáveis por nós mesmos. O Senhor diz a Ezequiel (18:20) que "o filho não levará a iniqüidade do pai, nem o pai a iniqüidade do filho; a justiça do justo ficará sobre ele, e a perversidade do perverso cairá sobre este”. Adão e Eva judaicos pagaram pela asneira que fizeram e nós sofremos individualmente como punição a eles, não a nós coletivamente. Caim pagou sozinho por ter assassinado Abel. Felizmente a tradição cristã, embora não nos isente de culpa, considera que estamos redimidos. Santo Agostinho sustentou (vide Cidade de Deus, XIII, cap.4) que caímos por nossa livre escolha, que a natureza seminal está viciada pelo pecado adâmico. Aquela foi a nossa primeira morte. A segunda será a nossa morte física, que é individual. O Adão cristão também é responsável por nossa miséria. Mas temos o Cristo, que é responsável por nossa redenção. Isto, pelo menos, é o que São Paulo disse aos Romanos ("Pois assim como por uma só ofensa veio o juízo sobre todos os homens para a condenação, assim também por um só ato de justiça veio a graça sobre todos os homens para a justificação que dá a vida” [Romanos 5;18]).

${ }^{6}$ Aristóteles, na Ética a Nicomaco (passim), Kant, na Crítica à Razão Prática (II,3).

${ }^{7}$ Leis, 3; Górgias, 480b.

${ }^{8}$ Timeu, 86.

${ }^{9}$ Ética a Nicômaco (vide Livro III, cap.5, 1113b).

${ }^{10}$ Riqueza das Nações, Liv. IV, cap.2. Adam Smith também dizia que nunca tinha visto o bem feito pelos que propagam que trabalham para o bem público.

${ }^{11}$ A denominação é utilizada por Adélia Cortina, da Universidade de Valência (El Pais, 2001).

${ }^{12}$ O marco inicial foi a campanha Our Common Concern - The Social Responsibility of the Corporate Sector, lançada pela Dinamarca em 1994 (Copenhagen Centre, 1998).

${ }^{13}$ Por exemplo o United Nations Global Impact de 2000, a ILO's Tripartite Declaration of Principles Concerning Multinational Enterprises and Social Policy (1997-2000) e o OECD Guidelines for Multinational Enterprises - 2000, do qual o Brasil, assim como o Chile e a Argentina, é signatário.

${ }^{14}$ De tal forma que a questão da responsabilidade social do cientista é hoje matéria de estudo e publicações especializadas. Os tópicos que tratam da validade social das pesquisas, da participação em debates públicos, da expertise e da denúncia da pseudo-ciência estão na ordem do dia. Essa discussão junta-se à preocupação principal hoje na área da responsabilidade moral dos cientistas, ligada em sua maior parte à bioética (Resnick, 1988). 
${ }^{15}$ Pesquisas realizadas nos EUA, como a relatada no Industry Week de 15 de janeiro de 2001, demonstram que cerca de metade das receitas contabilizadas acima da média do seu respectivo setor das empresas pode ser atribuída a sua ação social. Evidência disto é o crescimento, entre 1993 e 2000, de $180 \%$ do Dow Jones Sustainable Index contra o crescimento, no mesmo período, de $125 \%$ do Dow Jones Global.

${ }^{16} \mathrm{O}$ homo sapiens como homo faber e os resultados dessa redução foram tematizados por Bergson (1946).

${ }^{17}$ Desde os empiristas britânicos, a identidade, afirmada por Locke e negada por Hume, vem sendo estudada como reflexão, como uma relação "do mesmo", do que permanece, que se estende do passado ao futuro.

${ }^{18}$ Como ensinou Aristóteles, a imprudência e a ignorância deliberada são injustificáveis (vide Ética a Nicomaco, III, 6, 1113 b 30 - 1113 a 31).

${ }^{19}$ Leis III, cap. 5.

\section{ReferÊnCIAS Bibliográficas}

BENTHAN, J.

Collected works. Oxford: Oxford University Press, 1983.

BERGSON, $\mathrm{H}$.

L'évolution créatrice. Paris: Presses Universitaires de France, 1946.

CAMPOS, A. M. Accountability.

Revista de Administração Pública, v. 24, n. 2, fev./abr. 1990.

CHERQUES, H. R. T.

Max Weber e a ética nas organizações. Revista de Administração Pública, v. 31, n. 2, p. 5-22, 1997.

\section{COPENHAGEN CENTRE.} 1998-2001.

Disponível em: <http:// www.copenhagencentre.org/> Acesso em: [200?].
CRS.

European declaration of business against social exclusion. 1996-2001. Disponível em: <http://www.crseurope.org/> Acesso em: [200?].

FRIEDMAN, M.

The social responsibility of business is to increase its profits. New York Times Magazine, 13 Sept. 1970.

HABERMAS, J.

Teoría de la acción comunicativa. Madri: Taurus, 1987.

HENDERSON, D.

Misguided virtue: false notions of corporate social responsibility. London: Institute of Economic Affairs, 2001. Hobart paper 142. 
ILO'S tripartite declaration of principles concerning multinational enterprises and social policy (19972000).

Disponível em: <http:// oracle02.ilo.org:6060/vpi/ vpisearch.first $>$ Acesso em: [200?].

JONAS, H.

Le principe responsabilité.

Paris : Les Éditions du Cerf, 1990.

LADRIÈRE, P.

Pour une sociologie de l'éthique. Paris: Presses Universitaires de France, 2001.

LASCH, C.

O mínimo eu. São Paulo: Brasiliense, 1990.

MARCOUX, A. M.

Business ethics gone wrong. Chicago, CATO Today's Commentary, 2000.
OECD.

Guidelines for multinational enterprises - 2000. Disponível em: <http://www.oecd.org/daf/ investment/guidelines/> Acesso em: [200?].

PENNOCK, J. R.

The problem of responsibility. In: FRIEDRICH, C. (Org.). Responsibility. New York: Liberal Arts Press, 1960.

PIORE, M.;

SABEL, C. F.

The second industrial divide. New York: Basic Books, 1984.

RESNICK, D.

The ethics of science. London: Routledge, 1998.

UNITED NATIONS GLOBAL IMPACT 2000.

Um código de conduta elaborado pelo secretariado geral. Disponível em: <http:// www.unglobalcompact.org/> Acesso em: [200?]. 